\title{
Lietuvių kalbos pastoviųjų junginiu gramatinis variantiškumas
}

\section{Grammatical Variation of Lithuanian Formulaic Sequences}

\section{COMPUTATIONAL LINGUISTICS / KOMPIUTERINÉ LINGVISTIKA}

\section{Agnẻ Bielinskienè}

Vytauto Didžiojo universitetas, Lietuva

\section{Jolanta Kovalevskaitè}

Vytauto Didžiojo universitetas, Lietuva

\section{Erika Rimkutè}

Vytauto Didžiojo universitetas, Lietuva

\section{Laura Vilkaitè-Lozdienè}

Vilniaus universitetas, Lietuva
Straipsnyje analizuojamas dvieju pastoviuju junginių tipu - kolokaciju ir frazeologizmų - gramatinis variantiškumas. Pastovieji junginiai automatiškai nustatyti iš DELFI.lt tekstyno. Pastebėta, kad pastovieji junginiai tekstyne vartojami jvairiomis formomis, kurios negali būti laikomos reguliariomis kaitybinemis. Gramatinis variantiškumas suskirstytas i 1) darybini (kai viename junginyje pavartotas priešdèlis ar priesaga, o kitame, laikytiname variantu, nèra priešdèlio ar priesagos, pvz.: kilimo takas - pakilimo takas; ekonomikos krizé - ekonominé krizé; nutekejo protai - protu nutekejimas; 2) morfologini (kai varijuoja skaičiaus, giminès, dalyvių rūšies ir kt. gramatinès kategorijos, pvz.: euro jvedimas - euro jsivedimas; komisijos narys - komisijos naré; vykdomasis direktorius - vykdantysis direktorius) ir 3) sintaksini (kai varijuoja linksniai, prielinksniai, pvz., gauti nauda - gauti naudos; išskéstomis rankomis - su išskéstomis rankomis; ar isiterpia žodžių, pvz., aistringas [beisbolo] gerbéjas, keičiasi žodžių tvarka, pvz.: skirti dèmesi - dèmesi skirti).

Didesniu gramatiniu variantiškumu pasižymi kolokacijos, be to, ju rasta daug daugiau nei frazeologizmų (iš viso išanalizuota apie 14 tūkst. pastoviuju junginių), todèl gramatinis variantiškumas dažniau iliustruotas pavyzdžiais su kolokacijomis. Straipsnyje gramatinis variantiškumas aprašomas kokybiškai, nes iki šiol lietuvių kalbos pastoviuju junginių gramatinis variantiškumas tirtas mažai, todèl svarbu aprašyti pati reiškini, pateikti jo klasifikaciją.

REIKŠMINIAI ŽODŽIAl: pastovieji junginiai, kolokacijos, frazeologizmai, tekstynas, gramatiniai variantai, lietuviu kalba.
SAL 34/2019

Lietuvių kalbos pastoviuju junginiu gramatinis variantiškumas

Received 07/2018

Accepted 12/2018

\section{Anotacija}

ktu

Research Journal Studies about Languages No. $34 / 2019$

ISSN 1648-2824 (print) ISSN 2029-7203 (online) pp. $91-110$ DOI 10.5755/j01.sal.34.0.21214 

pažangiu technologiju institutas vykde projektą „Lietuvių kalbos pastoviuju žodžiu junginiu automatinis atpažinimas (PASTOVU)" ${ }^{1}$. Šiame projekte sukurta dabartinės rašytinès lietuviu kalbos pastoviujju žodžiu junginių tyrimo metodika, iki šiol netaikyta lietuvių kalbai, sudarytas tekstynu paremtas lietuvių kalbos kolokaciju žodynas ir pastoviuju junginių duomenu bazè.

Pradiniam dvižodžių pastoviųju junginių (toliau - PJ) atpažinimui ir ju statistinių savybių analizei taikyta 17 statistinių jverčiu (tai leksinès traukos jverčiai (angl. lexical association measures), pvz., abipuse informacija PMI (angl. (Pointwise) Mutual Information), logaritminio tiketinumo santykis LLR (angl. Log Likelihood Ratio), Dice koeficientas, logaritmuotas Dice koeficientas ir kt. (plačiau žr. Mandravickaitè et al., 2016). Kituose atpažinimo etapuose buvo taikomi penki mašininio mokymo metodai: Naivusis Bajesas (angl. Naïve Bayes), atsitiktiniu medžiu rinkinys (angl. Random Forest), atraminiu vektorių mašina SVM (angl. Support Vector Machine), sallyginiai atsitiktiniai laukai (angl. conditional random fields) ir rekurentiniai neuroniniai tinklai (angl. recurrent neural network). Galiausiai nuspręsta taikyti hibridini metodą: kai statistiniai metodai derinami su morfologine informacija ir panaudojami mašininiams metodams taikyti (plačiau žr. Bumbulienè et al., 2018).

Remiantis anksčiau minètais kompiuterinès lingvistikos metodais, PJ nustatyti 70 mln. žodžių DELFI.lt 2014-2016 m. publikuotų tekstų tekstyne² (toliau - tekstynas) (Bumbulienè et al., 2017), todèl turètu gerai atspindèti dabartinę rašytinę kalbą, konkrečiau - rašytinę periodiką.

Ankstesniame straipsnyje (Bielinskienė et al., 2017) aprašyti kolokaciju ir frazeologizmu kriterijai, kuriais remdamiesi minèto projekto lingvistai lengviau ir objektyviau atpažista, ar pastovusis junginys yra kolokacija ar frazeologizmas. Tačiau gana sudètinga ne tik atskirti PJ tipus, bet ir nuspręsti, ar dvi arba daugiau panašiu PJ formu - vis dar tas pats PJ, ar keli skirtingi junginiai, pvz., nauji metai - naujieji metai, nutekejjo protai - protu nutekéjimas, sugaišti laikq - sugaišti laiko. Ši problema susijusi su PJ variantiškumo reiškiniu.

Taigi šio straipsnio tikslas - išanalizuoti lietuviu kalbos kolokacijoms ir frazeologizmams būdingą gramatini variantiškumą, išryškèjusi iš ju vartosenos periodikos tekstuose. Iš anglu kalbos tyrimu matyti, kad PJ variantų daugiau fiksuojama būtent periodikoje (Moon, 1998, p. 121), todèl DELFI.lt tekstynas yra vertingas šaltinis PJ variantiškumui tirti. Tyrimas atliktas išsikèlus kelis uždavinius: aprašyti PJ variantiškumo sampratą bei klasifikacijas remiantis lietuvių ir kitų kalbų autorių darbais; išrinkti dvižodžius PJ, turinčius variantų; PJ gramatinius variantus suklasifikuoti i darybinius, morfologinius ir sintaksinius.

Šiame tyrime analizuojamos tik leksinès kolokacijos ir frazeologizmai, sudaryti iš dvieju žodžių. Leksinės kolokacijos apibrěžiamos kaip pastoviai vartojami bent dviejų prasminių žodžiu junginiai, sudarantys vieną gramatiškai taisyklingą reikšmès vienetą, kuris dèl leksinių apribojimu yra reguliariai pasikartojantis tam tikros diskurso bendruomenés sakytinèje ir rašytineje komunikacijoje. Frazeologizmais laikomi sustabareję, pastovios leksinès sudeties ir mažai kintančios gramatinès struktūros junginiai, atkuriami iš atminties, dažniausiai vaizdingi junginiai, kuriems būdinga nedaloma reikšmè. Tiek kolokacijos, tiek frazeologizmai yra pastoviujju žodžiu junginių klasès, taigi šie junginiai yra nusistovejję ir ịprasti kalbinejje bendruomenèje. Pagrindinis ju skirtumas yra tas, kad kolokacijos sudarytos iš sandų, kurių bent vienas turi išlaikyti savo prasmini savarankiškumą (pvz.: skirti dèmesio, didelis démesys, užkirsti keliq), o frazeologizmu atveju ivyksta viso junginio perprasminimas, visas junginys igyja naują reikšmę ir del to frazeologizmo reikšme tampa visiškai neskaidoma (pvz.: galvq apsukti, išskéstomis rankomis) (plačiau apie kolokacijų ir frazeologizmu sampratą, nusta-

\footnotetext{
1 Projektą finansavo Lietuvos mokslo taryba (projekto nr. LIP-027/2016), plačiau žr. http://mwe.lt/.

2 http://tekstynas.mwe.lt/
} 
tymo ir apibrěžimo problemas žr. Bielinskienè et al., 2017; taip pat žr. vieną iš svarbiausių kolokacijoms skirtų darbų Marcinkevičienè 2010).

Tiriant PJ didžiausias dèmesys paprastai kreipiamas i ju sustabarejimą ir leksini pastovumą, nors, pradejus tirti ju vartoseną tekstyne, išryškejja didelis variantiškumas, kuriam aprašyti ankstesniuose tyrimuose trūko gausių autentiškų duomenu iš tekstynų. Pritaikius anksčiau minètus tekstyny ir kompiuterinès lingvistikos metodus, buvo galima sukaupti daug reprezentatyvių vartosenos duomenų ir tai leido išsamiai aprašyti svarbią lietuvių kalbos PJ ypatybę - gramatini variantiškumą. Tai ypač svarbu analizuojant tokios fleksinès kalbos, kaip lietuviu, frazeologiją.

Šis tyrimas naujas tuo, kad lietuvių kalbos PJ variantiškumas analizuotas gana mažai; kiek plačiau žinomi, pavyzdžiui, frazeologizmu leksinio variantiškumo tyrimai (plačiau žr. skyriu „Pastoviujju junginių variantiškumas“). Šiame tyrime daugiausia gilinamasi i PJ gramatini variantiškumą. Jis šiame tyrime suvokiamas plačiai: tai to paties PJ skirtingi pavidalai, besiskiriantys žodžių darybos, morfologijos ir sintaksès elementais.

Teorinejje dalyje pirmiausia siekiama aprašyti PJ variantiškumo sampratą, aptariant daugiausia kitų kalbų analize pagrisstas variantiškumo klasifikacijas, pateikiamas užsienio autorių darbuose. Praktinejje straipsnio dalyje (žr. skyrių „Gramatiniai pastoviuju junginių variantai DELFI.lt tekstyne“) pateikiama kokybine PASTOVU projekte analizuotu PJ gramatinio variantiškumo analizè: aprašomi gramatinio variantiškumo tipai, jie iliustruojami pavyzdžiais, aptariama, kokios struktūros junginiai laikytini gramatiniais variantais (toliau - GV).

Straipsnyje nepateikiama kiekybinių duomenu, nes svarbiausia - aprašyti ir suklasifikuoti iki šiol lietuvių kalboje menkai tirtą gramatini PJ variantiškumą. Kita vertus, duomenys apie GV pateikiami remiantis gausia PJ medžiaga - išanalizuota apie 14 tūkst. automatiškai 70 mln. žodžiu tekstyne nustatytu PJ (daugiausia kolokaciju), kuriu dažnumas ne mažiau kaip 10 kartu. Kiekvienas PJ projekto metu sudarytoje duomenu bazejje yra fiksuojamas su visomis kaitybinèmis formomis (nuo kelių iki keliasdešimt), iš kurių atrinkti ir apibendrinti GV atvejai. Taip pat atskirai analizuota frazeologizmu (apie 3600), kurie nepateko tarp dažniausiu PJ. Iš šių frazeologizmu išrinkti GV ir suskirstyti pagal tipus kaip ir kolokacijos. Atsižvelgiant i tyrimo medžiagos kieki, tikètina, kad nustatyti tipiškiausi gramatinio varijavimo atvejai, o pateikti pavyzdžiai tinkamai atskleidžia lietuvių kalbos PJ gramatini variantiškumą.

Kitu kalbu - anglu (Moon, 1998), vokiečiu (Fellbaum et al., 2006), prancūzu (Abeillé, 1995) PJ tekstynu tyrimai rodo, kad daugumai PJ būdingas didesnis ar mažesnis variantiškumas. Pagrindinis visu PJ požymis yra vartojimo pastovumas ir dèl to dažnai PJ klasifikuojami pagal ju leksini ir gramatini sustabarejimą, tačiau, kaip rašo U. Heidas (2008, p. 344-346), tais pačiais lygmenimis galima fiksuoti ir PJ būdingą varijavimą: leksini varijavimą (angl. lexical variation), morfosintaksini varijavimą (angl. morphosyntactic variation) ir sintaksini varijavimą (angl. syntactic variation).

Tiek lietuvių, tiek užsienio autorių darbuose daugiau informacijos randama apie frazeologizmu variantus. Viena iš priežasčiu, kodèl kolokaciju variantiškumo tyrimu nera daug, galètu būti ta, kad kolokacijos dažnai nèra suvokiamos kaip sustabarejusios, nekintančios frazès. Pavyzdžiui, A. Wray (2002, p. 63) teigia, kad „kolokacijos yra iprastos, bet jokiu būdu ne išskirtinai tik tokios žodžių poros". Taigi kolokacijų variantiškumas gali būti suvokiamas kaip savaime suprantamas ir ne toks problemiškas. 0 frazeologizmai dažniausiai apibrěžiami kaip sustabarejję junginiai, taigi ju varijavimas pasidaro problemiškas. Todèl rašant apie PJ variantiškumą ir jo tipus šiame skyriuje daugiau remiamasi frazeologizmu variantiškumo aprašais. Tačiau kaip matyti iš šio tyrimo pavyzdžiu analizès, iš kolokaciju vartosenos išryš- 


\section{Pastoviųjų junginių variantiškumo samprata ir klasifikacijos}

kèja labai daug ivairių gramatinių formų, taigi yra pagrindo manyti, kad kolokaciju gramatinio variantiškumo raiška yra ivairesnè, o gramatinis variantiškumas (arba kai kurie jo tipai) gali būti būdingesni kolokacijoms nei frazeologizmams. Aprašant anglu kalbos PJ apibendrinama, kad didžiausiu variantiškumu pasižymi mažiausiai sustabarèję PJ (angl. syntactically flexible expressions) (Sag et al., 2002).

Tolesniuose teorinès dalies poskyriuose pirmiausia apibrèžiamas variantiškumas kaip reiškinys, pateikiamas kelių autorių požiūris i jo klasifikaciją; aprašyta, kaip lietuvių ir kitų šalių autoriai supranta leksinį ir šiam tyrimui ypač aktualu gramatini variantiškumą.

Stilistikos požiūriu variantu laikomas "kitas tos pačios reikšmės kalbos vieneto pavidalas“ (plg. Župerka, 2001, p. 28). Rašant apie variantus, lietuvių kalbotyroje dar vartojamas sinonimo terminas (plg. darybiniai, morfologiniai, sintaksiniai sinonimai) (Pikčilingis, 1969; 1975; Župerka, 2001; Valiulytė, 1998), nors, kaip matyti iš tolesnès apžvalgos, kalbant apie gramatiniais požymiais besiskiriančias PJ formas, dažniau vartojamas varianto terminas - būtent šis terminas pasirinktas toliau pristatomame tyrime ivardijant gramatinius variantus.

Analizuodama frazeologizmus A. Paulauskienè (1957) teigia, kad formalieji skirtumai (nevienoda sintaksine struktūra, leksiniai kintamieji) leidžia tam tikrus frazeologinius junginius laikyti variantais, jeigu tik išlaikoma ta pati reikšmè. F. Čermákas (2007, p. 93) frazemos ${ }^{3}$ variantą apibrèžia taip: variantas - pastovi ar nenusistovejjusi, palyginti nežymi struktūrinè ar semantinè frazemos modifikacija, nekeičianti tos frazemos funkcijos ir iš esmès nekeičianti frazemos reikšmès. Vadinasi, tam tikro frazeologizmo variantais gali būti laikomi panašios struktūros ir tos pačios reikšmès frazeologizmai, kurie, pavyzdžiui, gali skirtis žodžių formomis: kaip iš akies luptas ir kaip iš akiu luptas.

Frazeologijos darbuose minimi leksiniai, morfologiniai ir sintaksiniai, fonologiniai variantai; atkreipiamas demesys ir i tai, kad dažnai tas pats variantas apima kelias ypatybes (plg. Čermák, 2007, p. 93). E. Hemmerling (1989, p. 297) dar mini ir prozodinius, darybinius frazeologizmu variantus.

H. Burgerio (1998, p. 25-27) pateikiamoje vokiečiu kalbos frazeologizmu variantu klasifikacijoje aprašomi tokie frazeologizmų varijuojančių demenų požymiai:

a) skiriasi vieno ar keliu frazeologizmo dèmenu gramatiniai požymiai, pvz., seine Hand (vns.) / seine Hände (dgs.) im Spiel haben (pažodžiui: turèti savo rankq / rankas žaidime; reikšmè „visur dalyvauti");

b) gali varijuoti leksiniai dèmenys, plg.: ein schiefes Gesicht machen / ziehen (pažodžiui: kreivq veidq padaryti / traukti; reikšmè „reikšti nepasitenkinimą");

c) gali būti vartojamas ilgesnis ir trumpesnis to paties frazeologizmo variantas: sich etw. im Kalender anstreichen / sich etw. rot im Kalender anstreichen (pažodžiui: kq nors pabraukti kalendoriuje / ka nors raudonai pabraukti kalendoriuje; reikšmè „,pasižymèti ką nors kaip retenybę");

d) gali varijuoti frazeologizmo dèmenu tvarka, pvz.: aussehen wie Milch und Blut / wie Milch und Blut aussehen (pažodžiui: atrodyti kaip pienas ir kraujas / kaip pienas ir kraujas atrodyti; reikšmè „atrodyti sveikai ir jaunai“);

e) gali būti valentingumo skirtumu, atsižvelgiant i sakini, kuriame vartojamas variantas: sich die Schuhsohlen ablaufen nach etw. / um etw. zu bekommen (pažodžiui: batu padus numindyti dèl ko nors / batu padus numindyti, kad kq nors gautum; reikšmè „labai stengtis“).

${ }^{3}$ Frazema čia apima ir kolokacijas, ir frazeologizmus, ir posakius. 
Panašūs variantiškumo tipai skiriami ir ankstesniuose darbuose, pvz., Kuninas (1964, cit. iš Fedulenkova, 2005) klasifikuoja anglu kalbos frazeologizmu: a) leksinius variantus: big / fat / heavy / long / well-lined purse; b) morfologinius variantus: get into deep water / waters; c) sintaksinius variantus: blow away the cobwebs / blow the cobwebs away; d) pozicinius variantus: dot the its and cross the t's / cross the t's and dot the i's, e) kvantitatyvinius variantus: keep your chin up / chin up.

Remiantis čekų kalbos pavyzdžiais, matyti, kad F. Čermáko (2007) aprašyta variantiškumo sistema pagrista sintagminiu ir paradigminiu elementu varijavimu. Sintagminio variantiškumo tipais laikomi: 1) kvantitatyviniai variantai ir 2) kvalitatyviniai variantai.

Kvantitatyviniams priskiriami:

a) ilgesni tos pačios frazemos variantai: prinest nekomu neco k nosu (atnešti kam nors kq nors po nosimi) ir prinest nekomu neco az k nosu (atnešti kam nors ka nors net po nosimi);

b) trumpesni tos pačios frazemos variantai: dostat jich nepočitanych (likti jiems nenubaustiems) ir dostat nepočitanych (likti nenubaustiems). Kvalitatyviniams priskiriamos, pavyzdžiui, inversijos: sypat si hlavu popelem / sypat si popel na hlavu (barstyti sau galva pelenais / barstyti sau pelenus ant galvos).

Kvantitatyvinių ir kvalitatyvinių variantu skyrimo pagrindas - kiekybinè ir kokybinè frazeologizmo demenų kaita.

Tačiau sintagminio variantiškumo tipologijoje dar skiriami ir vadinamieji santykio variantai (angl. relational): i juos jeina tie atvejai, kai: a) variantas turi valdymą nurodanti dèmeni, juo dažnai būna prielinksniai su linksniais (ček. ohrnovat nos (nad nečim) (riesti nosi (prieš kq nors)) arba b) kaitomaji demeni, kuriuo dažnai eina linksnis (ček. merit (nekomu) dvojim metrem) (matuoti (kq nors) dvigubu matu). Matyti, kad santykio variantams taip pat būdinga ilgesnè struktūra, bet čia svarbu, kad papildomi demenys rodo sintaksini požymi, dèl to santykio variantai atskiriami nuo kvantitatyvinių variantu.

Kitu autoriu aprašuose minimi leksiniai variantai F. Čermáko (2007) pateikiami ir aiškinami kaip paradigminis variantiškumas (pvz., do bileho rana / dne, pažodžiui: iki balto ryto / baltos dienos; reikšmè „iki aušros“).

Pasirinkus klasifikuoti sintagminiu ir paradigminiu pagrindu, F. Čermáko (2007) klasifikacijoje nuosekliau integruojami nuo leksinio, morfologinio ir sintaksinio lygmens atsieti poziciniai variantai, ilgesni ir trumpesni variantai, taip pat ir variantai su valentingumą rodančiais demenimis. Tačiau ne visai aišku, kiek šioje klasifikacijoje atsispindi kitų klasifikacijų minimi variantu gramatiniai, tiksliau, morfologiniai, požymiai, pvz., H. Burgerio (1998) minimi variantai, kuriuose daiktavardis gali būti vartojamas ir vienaskaita, ir daugiskaita: seine Hand (vns.) / seine Hände (dgs.) im Spiel haben (pažodžiui: turèti savo rankq / rankas žaidime; reikšmè „visur dalyvauti“).

Iš kelių pateiktų klasifikaciju matyti, kad analizuojant variantiškumą svarbi atskiru demenų kaita ir frazeologizmo struktūros pokyčiai. Šiame straipsnyje labiausiai remtasi H. Burgerio (1998) siūlomu modeliu, ir varijavimo tipai skirstyti pagal varijuojančius dèmenis: PJ dèmenų gramatinių požymių varijavimą (ši varijavimo grupe skaidoma detaliau, atsižvelgiant i tai, kokie gramatiniai požymiai varijuoja, pvz., giminè, skaičius, laipsnis, linksnis ir kt.), PJ demenu tvarkos kaitą (atskirai neskiriami sintaksiniai ir poziciniai variantai, kaip kad Kunino (1964, cit. iš Fedulenkova, 2005)), valentingumo skirtumus (šio tyrimo duomenyse dažnai susiję su linksnio skirtumais). H. Burgerio išskirtas leksinių dėmenų varijavimas šiame straipsnyje toliau neanalizuojamas, tik trumpai pristatomi ankstesni lietuvių kalbos frazeologijos leksinio variantiškumo tyrimai (žr. skyrių „Pastoviujju junginių leksinis variantiškumas“). 


\section{Pastoviujų \\ junginių \\ leksinis \\ variantiškumas}

Kiek žinoma šio straipsnio autoriams, lietuvių kalbos frazeologizmai iki šiol aprašyti daugiausia tik leksinio variantiškumo požiūriu, t. y. tirti frazeologizmų leksiniai variantai. Remiantis E. Hemmerling (1989) pateikiamais lietuvių kalbos duomenimis, leksiniai variantai pagal vartojimo dažnumą sudaro gausiausią grupę: 915 iš 2300 frazeologizmų. Leksiniams variantams E. Hemmerling (1989, p. 298) priskiria tokias paraleliai funkcionuojančias frazeologizmu rūšis, kurios išlaiko tą pačią struktūrinę schemą, kiekybinę sandarą, semantinį identiškumą ir nepakitusią bendrą leksinę bei gramatinę viso frazeologizmo charakteristiką.

Iš E. Hemmerling (1989) pateiktos leksinių frazeologizmy dèmeny struktūrinės-gramatinès analizès matyti, kad a) varijuoti gali visos kalbos dalys, tačiau dažniausiai pasitaiko tai pačiai kalbos daliai priklausanti dèmenų kaita, ypač produktyvūs veiksmažodiniai ir daiktavardiniai demenys (tą patvirtino ir šio tyrimo duomenys, plačiau žr. skyriu „Pastoviuju junginiu gramatinis variantiškumas"), plg. i nagq suriesti / suvaryti arba nors i pasaulio galq / kraštq; b) varijuojantys dèmenys gali būti antonimai; vienos teminès grupès žodžiai; taip pat žodžiai, siejami hiperoniminiais-hiponiminiais santykiais.

Nors leksiniai variantai yra aiškiai atskiriami kaip variantu tipas, požiūriai, kas laikytina leksiniais variantais, gali kiek skirtis. Pavyzdžiui, E. Hemmerling (1989, p. 297) kiekybinès frazeologizmo demenu kaitos atvejus (ilgesni arba trumpesni to paties frazeologizmo pavidalą) priskiria leksiniams variantams ir laiko juos leksiniais kiekybiniais. Kaip ir E. Hemmerling (1989), R. Moon (1998) anglu kalbos PJ leksiniams variantams priskiria PJ, kuriems būdinga tai pačiai kalbos daliai priklausanti demenu kaita (kintamieji veiksmažodžiai, daiktavardžiai, būdvardžiai ir kt. kalbos dalys). Prie leksinių variantu R. Moon (1998) yra priskyrusi ir jterpimus (angl. insertions), taip pat sutrumpintus to paties PJ variantus (angl. truncations). Galima atkreipti dèmesi, kad R. Moon požiūris rodo kiek kitoki trumpesnių ir ilgesniu variantu aiškinimą: prie sutrumpinto varianto ji atitinkamai neskiria pailginto varianto. Pasak R. Moon, ilgesnis frazeologizmo variantas yra įterpimo (angl. insertions) rezultatas.

Atsižvelgiant i anksčiau aprašytas variantiškumo klasifikacijas, svarbu atkreipti demesi, kad ilgesnis ir trumpesnis frazeologizmo variantas gali būti vertinamas nevienodai. Pavyzdžiui, H. Burgerio (1998) pateiktas ilgesnis ir trumpesnis to paties frazeologizmo variantas: sich etw. im Kalender anstreichen / sich etw. rot im Kalender anstreichen (pažodžiui: kq nors pabraukti kalendoriuje / ka nors raudonai pabraukti kalendoriuje; reikšmè „pasižymèti ką nors kaip retenybę“). Kyla klausimas, kaip vertinti šio frazeologizmo papildymą prieveiksmiu raudonai: jeigu kaip ilgesni frazeologizmo variantą, tai tada tai yra kiekybinè demenų kaita. Plg. anksčiau pateiktą F. Čermáko pavyzdi: prinest nekomu neco k nosu (atnešti kam nors kq nors po nosim) ir prinest nekomu neco az $k$ nosu (kam nors kq nors net po nosim atnešti), kur antrame variante tiesiog pridedamas papildomas žodis (dalelytė). Tačiau jeigu imtume atvejus, kur vienam iš frazeologizmo demenu yra pridedamas pažyminys (laižyti antžmogiu batus, durys užtrenkiamos prieš nepažistamuju nosil), tokie atvejai jau galètu būti priskiriami gramatikai (sintaksei). Šiame straipsnyje laikomasi būtent šios pozicijos, t. y. kad pažyminiu ir kitu sakinio daliu isiterpimai (arba ilgesni tam tikro PJ variantai) yra gramatinio variantiškumo forma (plačiau žr. skyriu „Pastoviųju junginiu gramatinis variantiškumas“ apie PJ ¿siterpimus).

Tiriant PJ vartoseną, pastebèta, kad ir kolokacijos, ir frazeologizmai dažnai vartojami keliomis formomis. Pavyzdžiui, Lietuviu kalbos daiktavardiniu fraziu žodyne (Rimkutè et al., 2012) PJ pateikti ne viena (antraštine) forma, o visomis, kurios nustatant PJ automatiškai buvo atpažintos kaip dažniausios formos (pvz., frazeologizmas kabo ant plauko, kabojo ant plauko; kolokacija sveiko proto, sveiku protu ir pan.). Tokie atvejai šiame straipsnyje laikomi kaitybinemis formomis, o ne gramatiniais variantais. 
Vis delto analizuojant PJ tekstyne, pastebeta, kad PJ vartojami ivairiomis formomis, kurios negali būti laikomos tik kaitybinemis. Šis variantiškumas skirstytas pagal besiskiriančius PJ formos požymius:

- gramatines kategorijas, pvz., skaičiu (iš pradžios - iš pradžių), dalyvių rūši (vykdomasis direktorius - vykdantysis direktorius) ir t. t.;

- darybines žodžio dalis, pvz., priešdèlius (kraujo liejimas - kraujo praliejimas), priesagas (ekonomikos krizé - ekonominé krizét):

- žodžių tvarką ir galimybę isiterpti kitiems žodžiams (išsamiau žr. skyrių „Gramatiniai pastoviuju junginių variantai DELFI.lt tekstyne“).

Anksčiau aptartose klasifikacijose nèra daug informacijos apie skirtingu morfologinių arba sintaksinių požymių turinčius PJ variantus, bet, kaip minèta, tos klasifikacijos iš esmés remiasi informacija apie frazeologizmus. Analizuojant kolokacijas, matyti, kad ju variantai skiriasi ̨vairiais morfologiniais ir sintaksiniais požymiais, ir ta ìvairovè didesnè nei frazeologizmų GV.

Gramatinès kategorijos varijavimas arba darybinių žodžių dalių (priesagų, priešdèlių) atsiradimas žodyje - gana akivaizdūs gramatinio variantiškumo atvejai. Kita vertus, yra ne tokiu aiškiu atveju, pvz., PJ vartojimas kita kalbos dalimi (pvz., galvq laužyti ir galvos laužymas, auga kainos ir kainu augimas), kurie kitas kalbas analizuojančiu autorių vadinami transformacija, bet nebūtinai laikomi GV.

Pavyzdžiui, anglų kalbos PJ variantiškumo klasifikacijoje R. Moon (1998, p. 113-114) be leksinių variantų aprašo dar dvi kategorijas:

- sisteminį PJ variantiškumą (angl. systematic variation), kuris yra leksinio ir sintaksinio pobūdžio: tokie variantai apima, pvz., veikslo skirtumus (open one's eyes, keep one‘s eyes open);

- transformacijas. Prie šiu morfologiniu dariniu priskiriami, pvz., tokie atvejai, kai galima PJ vartosena neveikiamaja rūšimi (angl. passivization), taip pat čia minimi nominalizacijos atvejai (every cloud has a silver lining > silver lining, come and go > coming and going).

R. Moon transformacijas mini kaip atskirą variantų kategoriją, o, pavyzdžiui, F. Čermákas (2007) aiškiai transformaciju variantais nelaiko. Pasak F. Čermáko (2007, p. 93), „variantai turi būti atskirti nuo frazemų transformaciju, kurios skiriasi savo funkcija“, tiksliau, „variantas yra tos pačios frazemos modifikacija, išlaikanti tos frazemos funkciją, o transformacijomis sukuriamas naujas vienetas“ (Čermák, 2007, p. 122).

Aprašydamas transformaciju tipus, F. Čermákas (2007) skiria: leksikalizacijos atvejus (kvetomluva (struktūra daiktavardis + daiktavardis) (pažodžiui gèliu kalba; reikšmè „poetiška, vaizdinga kalba“), kaip lietuvišką pavyzdi galima pateikti dvišakni veiksmažodi padlaižiauti (iš frazeologizmo padus laižyti, struktūra daiktavardis + veiksmažodis) ir tokius atvejus kaip nominalizacija (čeku prekročit Rubikon > prekročeni Rubikonu - kirsti Rubikonq > Rubikono kirtimas). Dèl leksikalizacijos atveju galima sutikti: turbūt netikslu būtų sudurtini žodi laikyti junginio variantu, bet dèl nominalizacijos atveju šiame tyrime laikomasi R. Moon (1998) nuomonès, kad transformacijos turètu būti itraukiamos i variantiškumo klasifikacija. Šio tyrimo medžiagoje rasta daug transformaciju atveju, ypač tarp kolokaciju, todel čia transformacijos laikomos gramatiniu variantiškumu (plg. iš ieškoti adatos šieno kupetoje > adata šieno kupetoje; nutekejjo protai > protu nutekèjimas).

Žodžių tvarkos kaita ir galimybè isiterpti kitiems žodžiams šiame straipsnyje laikomi ne morfologinio, o sintaksinio variantiškumo tipais. Žodžių tvarkos kaita (pvz., daryti jtakq ir itakq daryti) jau minèti frazeologizmu variantiškumo klasifikacijose (pvz., Kuninas, 1964,

4 Šiame straipsnyje nesigilinama į kalbos taisyklingumo reikalavimus ir aprobuotają terminiją. Pateikiami net ir kalbos normų neatitinkantys PJ, pavartoti DELFI.lt tekstyne ir automatiškai jame nustatyti kaip PJ. 
cit. iš Fedulenkova, 2005; Burgeris, 1998). Mokslininku šiek tiek tyrinètas ir kolokaciju dèmenų tvarkos varijavimas. Pavyzdžiui, R. Krishnamurthy'is et al. (2004) padare išvadą, kad kai kurie kolokatai yra poziciškai laisvi (angl. position free), o kiti - poziciškai priklausomi (angl. position dependent). Poziciškai laisvi kolokatai gali būti vartojami tiek prieš pagrindini kolokacijos žodi, tiek po jo, tarp ju galimi skirtingo ilgio isiterpimai. Poziciškai priklausomi kolokatai turi savo iprastą poziciją, pavyzdžiui, iškart prieš pagrindini žodị. Tačiau, ištyrę savo tekstyno duomenis, autoriai teigia, kad poziciškai laisvos kolokacijos tekste gana retos. Poziciškai priklausomi kolokatai dažnai sudaro frazeologizmus, kurių dèmenys negali būti sukeičiami vietomis (pvz., never mind) (Krishnamurthy et al., 2004, p. 83). Kitais atvejais kolokacijos yra poziciškai priklausomos del kalbos daliu junglumo dèsningumu, pavyzdžiui, first year - skaitvardis pažymi daiktavardi. Taip pat autoriai nurodo, kad pasitaiko nemažai atveju, kai teoriškai kolokacija galètų būti poziciškai laisva, bet praktiškai dèmenys beveik visada vartojami ta pačia tvarka (pvz., old man, understand English, good example).

Tokia išvada leistų manyti, kad dauguma PJ turi iprastą žodžių tvarką. Tačiau, analizuojant tekstyno duomenis, matyti, kad vis dèlto pasitaiko PJ žodžiu tvarkos kaitos atveju. Iš dalies būtu galima daryti prielaidą, jog žodžių tvarkos varijavimas būdingesnis lietuvių nei, pavyzdžiui, anglu kalbai, nes dažnai teigiama, kad lietuvių kalbos žodžiu kalba yra laisva (pvz., Klimas, 2002). Tačiau V. Ambrazas (2012) daro išvadą, kad toks bendras teiginys ne visada yra pagristas. Anot jo, nors lietuvių kalbos žodžių tvarka dažnai nẻra griežta, bet daugeliu atveju aiškiai jaučiama, kuri tvarka neutrali, o kuri - stilistiškai žymèta (Ambrazas, 2012). Išanalizavus PJ pavyzdžius tekstyne, akivaizdu, kad žodžių tvarkos kaita įmanoma, bet nèra labai dažna. Taigi R. Krishnamurthy'io et al. (2004) išvada, kad poziciškai priklausomi kolokatai būdingesni nei poziciškai laisvi, atrodo, tinka ir lietuviu kalbai.

Su žodžiu tvarkos variantiškumu labai susijusi ir žodžiu isiterpimo i PJ galimybè. Analizuojant PJ variantus, akivaizdu, kad žodžiu isiterpimas būdingas tiek kolokacijoms, tiek frazeologizmams. Svarbu pabrèžti, kad šiame tyrime junginiai su isiterpimais nelaikomi naujais ilgesniais PJ (plg. Čermák, 2007). Pats junginys nesikeičia (ji sudaro tos pačios tu pačiu žodžiu formos), tiesiog PJ vartojamas neištisine forma. Pavyzdžiui, analizuojant jungini laikq leidžia ir laikq ramiai leidžia, abiem atvejais PJ yra leisti laikq, tik antruoju atveju vartojama neištisinè jo forma. Tokie atvejai šiame tyrime laikomi sintaksiniais PJ variantais.

PJ vartojimas neištisine forma itin būdingas kolokacijoms, nes kolokacijos paprastai suvokiamos ne kaip sustabarejusios frazès, o kaip žodžiu ypatybè būti pavartotiems drauge (angl. co-occur). Reikètų atkreipti dèmesi, kad toks žodžių vartojimas drauge nebūtinai reiškia, kad žodžiai turi būti vartojami greta. S. Evertas (2009) teigia, kad žodžių vartojimas drauge gali būti suvokiamas skirtingai. Jis skiria tris atvejus:

- paviršinis vartojimas drauge (angl. surface co-occurrence) (pvz., Firth, 1957): žodžiai dažnai vartojami drauge per tam tikrą atstumą vienas nuo kito;

- tekstinis vartojimas drauge (angl. textual co-occurrence): žodžiai vartojami drauge viename teksto vienete, paprastai sakinyje ar frazeje;

- sintaksinis vartojimas drauge (angl. syntactic co-occurrence): žodžiai vartojami drauge ir juos sieja tiesioginis sintaksinis ryšys.

Paviršinio vartojimo drauge atveju galimas isiterpiančiu žodžiu skaičius varijuoja priklausomai nuo tyrimo tikslo ir lingvistu pasirinkimo. Dažnai naudojamas \pm 4 žodžiu atstumas (pvz., Sinclair, 1991; Krishnamurthy et al., 2004). Tekstinis vartojimas drauge leidžia išskirti ir tirti silpniau susijusias (mažesnius tarpusavio traukos iverčius turinčias) kolokacijas (Evert, 2009). Sintaksinis vartojimas drauge mažiausiai gristas atsitiktiniais pasirinkimais (tarkim, 
koks atstumas tarp kolokatų leidžiamas, koks jau ne), nes sintaksinis ryšys tarp žodžių aiškiai nustatomas. Pavyzdžiui, sintaksinio vartojimo drauge atveju kolokaciją galetu sudaryti veiksmažodis ir jo tiesioginis objektas, pažyminiu einantis būdvardis ir jo pažymimas daiktavardis ir t. t. Šiame tyrime pasirinktas sintaksinio vartojimo drauge kriterijus, ir junginys su ¡siterpimais laikomas kolokacija tik tada, kai abu PJ demenys sintaksiškai susiję.

Iš ankstesnių tyrimų matyti, kad lietuvių kalboje isiterpimai tarp kolokacijos demenu gana dažni. Rankomis anotuotame bandomajame 72 tūkst. žodžiu DELFI.lt tekstyne ${ }^{5}$ junginiai su ¿siterpimais sudare apie 17 \% visu pažymètų PJ (Bielinskienè et al., 2017). Iš duomenų matyti, kad dominuoja vienažodžiai isiterpimai, nemažai ir dvižodžių isiterpimu, ilgesni isiterpimai nèra labai būdingi.

Apibendrinant galima teigti, kad apžvelgtuose teoriniuose darbuose leksiniais ir gramatiniais PJ variantais laikomi to paties PJ pavidalai, kuriuose, nepaisant leksikos, morfologijos, sintaksès ar kitokiu skirtumu, išlaikoma ta pati reikšmè. Kai kuriose klasifikacijose (plg. Čermák, 2007) PJ variantais laikytini tie, kurie išlaiko ne tik reikšmę, bet ir tą pačią funkciją, todèl, pvz., nominalizacijos atvejai (ieškoti adatos šieno kupetoje > adata šieno kupetoje; nutekejo protai > protu nutekejjimas) dè pakitusios funkcijos skirtingu autoriu gali būti vertinami nevienodai. Šiame tyrime nominalizacija laikoma gramatinio variantiškumo forma.

Analizuojant variantiškumo klasifikacijas galima pastebèti daugiau autorių nuomoniu skirtumu, kaip traktuojamas panašus reiškinys: tarkim, vertindami ilgesni PJ variantą, kai kurie autoriai priskiria tokius atvejus leksiniam variantiškumui, kiti, ypač jeigu kalbama apie pažyminių ir kitu sakinio daliu isiterpimus, vertina sintaksiškai ir laiko gramatinio variantiškumo forma. Šiame straipsnyje pasirinkta antroji pozicija: pažyminiu ir kitu sakinio daliu isiterpimai (arba ilgesni tam tikro PJ variantai) yra gramatinio variantiškumo forma (pvz., laikq leidžia ir laikq ramiai leidžia) ir laikomi sintaksiniais PJ variantais.

Apžvelgtuose teoriniuose darbuose daugiausia rašoma apie frazeologizmy variantiškumą, 0 šiame tyrime didžiają dali PJ sudaro kolokacijos, todèl teorinèje dalyje aptartos klasifikacijos buvo tik vienas iš orientyru, kuriuo remiantis buvo sudaryta toliau pristatoma gramatinio variantiškumo klasifikacija. Remtasi H. Burgerio (1998) siūlomu modeliu, ir varijavimo tipai skirstyti pagal PJ demenų gramatinių požymių varijavimą (pvz., giminè, skaičius, laipsnis, linksnis ir kt.), PJ demenu tvarkos kaitą, valentingumo skirtumus (šio tyrimo duomenyse dažnai susiję su linksnio skirtumais). Vis dèlto šiame tyrime klasifikaciją labiausiai nulèmè pati tiriamoji medžiaga, kuria remiantis ir buvo sudaryta lietuvių kalbos PJ gramatinio variantiškumo klasifikacija ir aprašytas gramatinis variantiškumas.

Šioje dalyje aprašomi gramatinio variantiškumo tipai, kurie iliustruojami pavyzdžiais iš DELFI.lt tekstyno. Aptariama, kokios struktūros PJ būdingi GV. Leksinis variantiškumas, arba leksiniai variantai, čia netiriami (pvz., išnešti kudašių / išnešti kaili). Be to, netiriami tokie atvejai, jei kai kurios vartosenoje pastebetos PJ formos formaliai yra panašios ir gali atrodyti kaip variantai, bet dèl reikšmès skirtumų negali būti laikomos to paties PJ gramatiniais variantais. PJ gramatiniais variantais nelaikomi šie atvejai:

a) kai priešdèlis pakeičia junginio reikšmę, plg. frazeologizmų porą apsukti galvq (reikšmè: „apgauti“) ir pasukti galvq (reikšmè: ,intensyviai mąstyti“)';

b) kai pridèta priesaga suteikia kitą reikšmę: asmens duomenys - asmeniniai duomenys;

5 Šiame tekstyne rankomis buvo žymètos kolokacijos ir frazeologizmai. Plačiau apie anotavimą, jo metu kilusias problemas žr. Bielinskienè et al., 2017.

${ }^{6}$ Kartais frazeologizmu poroje tas pats junginys (plg. pasukti galvq) gali būti ir kolokacija, ir frazeologizmas, tačiau tokiu atveju imama frazeologizmo reikšmè. Kolokacijos ir frazeologizmo pora nelaikytina variantais.

Gramatiniai pastoviųjų junginių variantai DELFI.It tekstyne 
c) dèl gramatinės kategorijos, pvz., skaičiaus: vienaskaita rodo konkretu pavadinimą (Šiaurés jūros laivynas), daugiskaita vartojama kaip terminas (jūru laivynas);

d) dè kelių gramatinių kategoriju, pvz., jvardžiuotinès formos ir daugiskaitos: trečia valstybe - trečiosios valstybés; del skirtingu linksniu ir daugiskaitos: sumokèti dali - sumokèti dalimis ir pan.

Tiesa, kartais reikšmès niuansai, ypač perteikiami darybos priemonemis, labai menki, tačiau dèl darybinès reikšmès skirtybiu čia nelaikomi variantais, pvz.: ekonominis sprendimas ekonomiškas sprendimas; politinis - politizuotas sprendimas; praktinis sprendimas - praktiškas sprendimas; išmanus sprendimas - sumanus sprendimas.

Kaip minèta, gramatiniu variantiškumu nebus laikomas reguliarus kaitybiniu formu varijavimas: apgalvotas sprendimas - apgalvoto sprendimo, apgalvotam sprendimui... (linksniu); vyksiančios rungtynés - vykusios rungtynés (laiko variantai)7, išskyrus tada, kai dominuoja viena kuri PJ forma, kuri laikoma tokio junginio lema (antraštine forma), nes tik ji ir tevartojama tekstyne arba sudaro didžiają visų kaitybinių formu dali, pvz., artimiausiais metais; artimiausiomis dienomis; automobilio rakteliai; vadovu teigimu ir pan. Tokiais atvejais GV laikomos ir reguliariai kaitomos formos, pvz., artimiausiomis dienomis (ši forma dominuoja) - artimiausios dienos (tai apibendrinta kitu šio PJ pavartojimo atvejų forma, nes dar vartojamos formos artimiausias dienas, artimiausioms dienoms), t. y. daiktavardiniams junginiams būdinga linksnių kaita.

Taigi šiame tyrime GV laikomi vienodos ar panašios leksinès sudeties (bet, pvz., su galimais ¡siterpimais, varijuojančiais prielinksniais, skirtingos darybos gramatinemis formomis); labai artimos ar tos pačios reikšmės; skirtingos gramatinès sandaros (jei varijuoja gramatiniai požymiai); imanomi pakeisti vienas kitu PJ (plg. Valiulytė, 1998, p. 9).

Gramatinis variantiškumas suvokiamas gana plačiai, kaip:

a) darybinis - kai bendrašakniai žodžiai (Župerka, 2001, p. 37) varijuoja savo daryba: ekonomikos krizé - ekonominé krizé; nutekejo protai - protu nutekejjimas (žr. 1 lentelę);

b) morfologinis - kai skiriasi to paties žodžio gramatinès formos ir jos nelaikomos reguliaria kaityba: užduoti klausima - užduotas klausimas; euro jvedimas - euro jsivedimas (žr. 2 lentelę);

c) sintaksinis - panašios leksinès sudèties, bet skirtingos gramatinès sandaros sintaksinès konstrukcijos (taip pat kai issiterpia žodžiu, keičiasi žodžių tvarka ir pan.): gauti naudq gauti naudos; sukti galvq - galvq sukti (žr. 3-5 lenteles).

Toliau pateikiamoje gramatinio variantiškumo klasifikacijoje nurodomi kiekvieno tipo požymiai (pvz., morfologiniu variantu požymiai - giminè, skaičius, linksnis ir t. t.). GV aptariami pagal PJ tipus, t. y. atsižvelgiant i pagrindini PJ demeni skiriami daiktavardiniai, veiksmažodiniai, būdvardiniai, prieveiksminiai junginiai. Tikimasi, kad taip išryškés junginio tipo ir GV tipo sąsajos. Iš anglu kalbos duomenu (plg. Moon, 1998, p. 121) matyti, kad variantiškumas itin būdingas veiksmažodiniams junginiams, ne toks būdingas būdvardiniams ir daiktavardiniams. Remiantis šio tyrimo duomenimis, GV būdingesni veiksmažodiniams ir daiktavardiniams, rečiau būdvardiniams ir kitų kalbos dalių PJ.

Pastoviưju junginių GV aprašyti pateikiant daugiausia kolokacijų pavyzdžių, nes, kaip minèta ¡vade, kolokacijų tiriamojoje medžiagoje yra gerokai daugiau.

\section{Darybinis variantiškumas}

Darybinis variantiškumas šiame tyrime apima priešdèlių, priesagu, veiksmažodžio ir veiksmažodinio daiktavardžio formų variantus (žr. 1 lentelę).

\footnotetext{
${ }^{7}$ Laikų varijavimas (taip pat nuosakų ir asmenų) kitur minimas prie morfologinio variantiškumo (sinonimikos)
} (Pikčilingis, 1969; Župerka, 2001). 
1 lentelè. Darybinis variantiškumas

\begin{tabular}{|c|c|}
\hline Darybinio variantiškumo tipai & Darybinio variantiškumo pavyzdžiai \\
\hline \multicolumn{2}{|r|}{ 1. Daiktvardiniai pastovieji junginiai } \\
\hline \multicolumn{2}{|r|}{ 1.1. Priešdèlių variantiškumas } \\
\hline $\begin{array}{l}\text { 1.1.1. Be priešdèlio - su } \\
\text { priešdèliu }\end{array}$ & $\begin{array}{l}\text { Kraujo liejimas - kraujo praliejimas }\left(F^{8}\right) \text {; kilimo takas - pakilimo takas; baigti rungtynes - pabaigti } \\
\text { rungtynes; vykusios rungtynès - jvykusios rungtynés; žaistos rungtynés - sužaistos rungtynės; sprendimo } \\
\text { vykdymas - sprendimo ivykdymas; malonus darbas - nemalonus darbas; mégstamas darbas - } \\
\text { nemėgstamas darbas; didelè partija - nedidelè partija }\end{array}$ \\
\hline 1.1.2. Skirtingi priešdèliai & Užbaigtos rungtynės - pabaigtos rungtynės \\
\hline $\begin{array}{l}\text { 1.1.3. Kita (priešdèlinis žodis - } \\
\text { priešdèlinis žodis su neiginiu) }\end{array}$ & $\begin{array}{l}\text { Apgalvotas sprendimas - neapgalvotas sprendimas; pagristas sprendimas - nepagrįstas sprendimas; } \\
\text { pralaimètos rungtynės - nepralaimètos rungtynès }\end{array}$ \\
\hline
\end{tabular}

\subsection{Priesagu variantiškumas}

\subsubsection{Daiktavardžio kilmininkas - priesagos -inis vedinys}

Ekonomikos krizè - ekonominè krizè; medicinos pagalba - medicininė pagalba; nakties paukštis naktinis paukštis (F); navigacijos sistema - navigacinè sistema; interneto svetainè - internetinè svetainè; turnyro lentelè - turnyrinè lentelé; vietos gyventojas - vietinis gyventojas; valstybés institucija - valstybinè institucija; finalo rungtynès - finalinès rungtynès; pasaulio čempionatas - pasaulinis čempionatas; arbitražinis teismas - arbitražo teismas

1.2.2. Viena priesaga - dvi priesagos

1.2.3. Skirtingos priesagos

1.2.4. Be priesagos - su priesaga

priesaga

Sprendimo vykdymas - sprendimo vykdytinumas; tolesnis sprendimas - tolimesnis sprendimas; pensinis amžius - pensijinis amžius

Kūrybingas sprendimas - kūrybiškas sprendimas

Skubus sprendimas - skubotas sprendimas; žaibo greičiu - žaibo greitumu (F); naujametè naktis naujametinè naktis; iki soties - iki sotumo

\section{Veiksmažodiniai pastovieji junginiai}

\subsection{Priešdèlių variantiškumas}

Augti kaina9 - išaugti kaina; kilti problema - iškilti problema; kelti klausimą - iškelti klausimą; daryti išvadą - padaryti išvadą; kalnus versti - kalnus nuversti (F); koją kišti - koją pakišti (F); kojas tiesti - kojas ištiesti (F); kraujas virti - kraujas užvirti (F); laiką leisti - laiką praleisti; kreipti dèmesi - atkreipti dèmesi; galvą sukti - galvą pasukti (F); medumi tepti - medumi patepti (F); metai bègti - metai prabègti; velnias nešti - velnias nunešti (F); likti atmintyje - išlikti atmintyje; skųsti sprendimą - apskųsti sprendimą; galvą lenkti - galvą nulenkti (F); gadinti orą - pagadinti orą; imtis veiksmu - nesiimti veiksmų; semtis patirties pasisemti patirties; dalintis patirtimi - pasidalinti patirtimi; lietis kraujas - besilieti kraujas (F); saule leistis - saule nusileisti

2.1.1. Be priešdèlio - su priešdèliu

\subsubsection{Skirtingi priešdèliai}

2.1.3. Kita: - priešdèlinis žodis - priešdèlinis žodis su neiginiu; - nepriešdèlinis žodis priešdèlinis žodis su dviem priešdeliais

\subsubsection{Be priesagos - su} priesaga

\subsubsection{Skirtingos priesagos}

2.3. Veiksmažodžio veiksmažodinio daiktavardžio formų variantiškumas

\section{galvą nulenkti - galvą palenkti (F); koją pakelti - koją iškelti (F); pabaigti rungtynes - užbaigti rungtynes}

Priimti sprendimą - nepriimti sprendimo; pateikti duomenis - nepateikti duomenų; rankas nuleisti rankų nenuleisti; problema iškilti - problema neiškilti;

Kaina kilti - kaina nepakilti; mokèti mokesti - nesumokèti mokesčio

\subsection{Priesaginiai variantai}

Priimti sprendimą - priiminèti sprendimus; jvesti eurą - ivedinèti eurą; šilti oras - šiltèti oras

Patirtimi dalytis - patirtimi dalintis

Augti kaina - kainų augimas; kaulus laužyti - kaulų laužymas (F); konvertuoti valiutą - valiutos konvertavimas; licenciją išduoti - licencijos išdavimas; galvą laužyti - galvos laužymas (F); galvą sukti galvos sukimas (F); rinkti seimą - seimo rinkimai; svarstyti seime - svarstymas seime; igyvendinti sprendimą - sprendimo igyvendinimas; priimti sprendimą - sprendimo priemimas; jvesti eurą - euro jvedimas; nagrinèti teisme - nagrinejimas teisme

\footnotetext{
8 Čia ir kitur raide $\mathrm{F}$ žymima frazeologizmų pora.

9 Kai kurių subjektiniu junginių lemos gali atrodyti ne visai rišlios. Tekstyne tokie junginiai pavartoti jvairiomis nuosakų ir laikų formomis, o bendratis pasirinkta kaip visas kaitybines formas apibendrinanti gramatinè forma.
} 
Iš priešdèlinių variantų dominuoja PJ, kurių viena forma nepriešdèlinè (arba ir priešdèlinè), o kita - su neigiamuoju priešdèliu (racionalus sprendimas - neracionalus sprendimas; pralaimètos rungtynés - nepralaimètos rungtynés; priimti sprendima - nepriimti sprendimo; kaina kilti - kaina nepakilti) (žr. 1 lentelę 1.1.1, 1.1.3, 2.1.3 punktus). Šis variantiškumo tipas būdingas tiek daiktavardiniams, tiek veiksmažodiniams PJ ir yra iš esmès reguliari tokio tipo junginiu daryba. Atkreiptinas dèmesys, kad kai kurios priešdèlinès formos gali būti laikomos ir veikslo kategorijos kaita, t. y. viena forma eigos, o kita jvykio veikslo. Kaip teigia A. Judžentis (2012, p. 148), ,[g]ramatinès veikslo kategorijos raiškos priemonės lietuviu kalboje yra veiksmažodžiu darybos (skaitè : perskaitè) bei kaitybos (skaitè : skaitydavo) afiksai“. Tokias formas nuspręsta laikyti žodžių darybos, o ne morfologijos variantais, nors pripažistama, kad tai diskusinis gramatinio variantiškumo klasifikacijos aspektas.

Be aptartojo priešdèlio ne-, kaip nepriešdèlinès formos variantas vartojami ir kiti priešdèliai: pra-, pa-, su-, i- (daiktavardiniuose junginiuose), at-, ap-, iš-, pa-, pra-, nu-, už- (veiksmažodiniuose junginiuose), pvz.: kraujo liejimas - kraujo praliejimas; auga kaina - išauga kaina (žr. 1 lentelę 1.1, 2.1 punktus). Veiksmažodiniu PJ priešdèliu variantu jvairovè daug didesnè nei daiktavardinių. Labai nedaug atveju, kai varijuoja skirtingi priešdèliai: galvq nulenkti galva palenkti (F) (reikšme „nusižeminti“); pabaigti rungtynes - užbaigti rungtynes.

Vienas dažniausių priesaginio variantiškumo tipų, kai PJ daiktavardžio kilmininkas variantiškas PJ su priesaga -inis. Tarp šių formu ryški sinonimija, nors kai kur kalbos taisyklingumo požiūriu priimtinesnè daiktavardžio kilmininko forma (ekonomikos krizé - ekonominè krizé; medicinos pagalba - medicinine pagalba) (žr. 1 lentelę 1.2.1 punktą; išsamiau i kalbos normas nesigilinama).

Šiame tyrime GV pasirinkta laikyti ir tokias formas, kai veiksmažodis varijuoja su to paties tipo veiksmažodiniu daiktavardžiu, juolab kad tokių formu pasitaikè tikrai nemažai: augti kaina - kainu augimas; kaulus laužyti - kauly laužymas (F) (žr. 1 lentelę 2.3 punktą), nors, kaip matyti iš teoriniu darbu apžvalgos, diskutuotina, kokiu variantiškumo tipu laikyti šias formas.

Pasitaike atvejų, kai variantiškumas reiškiamas keliomis darybos priemonėmis, pvz., dviem priešdèliais: priešdèline forma su neiginiu (kaina kyla - kaina nepakyla) (žr. 1 lentelę 2.1.3 punktą).

\section{Morfologinis variantiškumas}

Iš visu GV tipu didžiausia ivairove pasižymi morfologinis variantiškumas. Jis būdingas daiktavardiniams, veiksmažodiniams, būdvardiniams ir prieveiksminiams PJ. Juo laikomas tokių gramatinių kategoriju varijavimas: giminès, skaičiaus, apibrèžtumo, sangrąžos, laipsnio, ilguju ir trumpuju formu, veiksmažodžio asmenuojamuju ir neasmenuojamuju formu, dalyvių rūšių (žr. 2 lentelę). Gramatinis variantiškumas būdingiausias asmenuojamosioms ir neasmenuojamosioms veiksmažodžio formoms, pvz.: bégti metai - bégantys metai; vykdyti darbq - vykdomas darbas; skųsti sprendima - skundžiamas sprendimas. Iš pirmo žvilgsnio gali susidaryti ispūdis, kad tai reguliari kaityba, todèl tokių formu lyg ir nereikètu laikyti GV. Tačiau būtina pabrežti, kad asmenuojamosios ir neasmenuojamosios veiksmažodžio formos laikomos GV tik tada, kai neasmenuojamosios formos (dažniausiai dalyviai) vartojami labai dažnai ar netgi dažniau nei asmenuojamosios; paprastai dominuoja vienos kurios nors rūšies vieno laiko dalyvių forma.

Ivardžiuotinių ir neivardžiuotinių formų variantiškumas daro skirti tarp termino ir netermino. Ivardžiuotines formos būdingos PJ, kurie yra terminai: bandomas automobilis - bandomasis 
automobilis; gyvenama vieta - gyvenamoji vieta. Bet taip pat PJ gali būti suteikiama pabrèžiamoji, išskiriamoji reikšmè: laimejusi partija - laimejjusioji partija; naujas pirmininkas naujasis pirmininkas; minèta ministerija - minètoji ministerija.

Termininè reikšmè atsiranda ir tada, kai varijuoja dalyvių rūšys. Terminams būdinga neveikiamoji dalyvio rūšis: vykdantysis direktorius - vykdomasis direktorius. Tačiau kitais variantiškumo atvejais gali ir nebūti termino, tik varijuoti skirtingu dalyvių rūšiu formos: praejęs sezonas - praeitas sezonas; numatytas darbas - numatomas darbas; pasiaukojamas darbas - pasiaukojantis darbas.

PJ gali būti laikomas terminu ir dèl skaičiaus. Remiantis analizuojama medžiaga, vienaskaita arba daugiskaita lemia, ar PJ bus terminas, pvz., autoriaus (-iu) teisés - autoriaus teise; piliečio teisés - piliečio teisè, kurių pirmiau pateikti pavyzdžiai su pagrindinio žodžio teisés daugiskaitos forma laikomi terminais.

Kai PJ būdingas laipsnio variantiškumas, gali varijuoti visų trijų laipsnių formos, bet dažniausiai varijuoja dvieju: nelyginamojo ir aukščiausiojo: gražūs metai - gražiausi metai; nelyginamojo ir aukštesniojo laipsnio: pigus sprendimas - pigesnis sprendimas. Beje, tam tikras laipsnis gali būti būdingas ir terminams, pvz., aukštesnioji mokykla. Jau minèta, kad ir kolokacijos gali būti vartojamos tik kuria nors dominuojančia forma, pvz., ankstesniais metais. Tokiu atveju būtent ši forma laikoma antraštine.

Analizuojant skaitvardžių variantiškumą, matyti, kad dažniausiai varijuoja kiekiniai pagrindiniai ir kiekiniai dauginiai skaitvardžiai, bet tai gali būti nulemta pagrindiniu dèmenų, nes analizuotuose duomenyse pasitaikè nemažai daugiskaitos formos daiktavardžių, pvz., du metai - dveji metai, penkios rungtynès - penkerios rungtynès.

Be minètu morfologinio variantiškumo atveju dar rastas: giminès (tarybos narys - tarybos narè); sangrąžinès ir nesangrąžinès formu (valiutos keitimas - valiutos pasikeitimas; pastatyti automobili - pasistatyti automobili); kaitomuju ir nekaitomuju formu (trisdešimt metu trisdešimtis metų) variantiškumas (žr. 2 lentelę).

Kaip minèta prie priešdèlinių formu (žr. poskyri „Darybinis variantiškumas“), neretai būna susijusios kelios gramatinès kategorijos: kalbant apie priešdèlinius veiksmažodžius, ne visada žodžiu darybos priemones galima atskirti nuo veikslo kategorijos. Analizuojant sangrąžines formas, susiduriama su dilema, ar tai atskira veiksmažodžių ir iš jų padarytu formu gramatinè kategorija, ar tranzityvumo kategorijos dalis. Plg. Dabartinés lietuviu kalbos gramatikoje (1996, p. 287) teigiama, kad „[d]augelis sangrąžinių veiksmažodžiu priešinami nesangrąžiniams tranzityvumo pagrindu: nesangrąžinis veiksmažodis esti tranzityvinis (prausti, versti, kartoti), o atitinkamas sangrąžinis - intrazityvinis (praustis, verstis, kartotis)." Nors vèliau (p. 288) priduriama, kad ne visi sangrąžiniai veiksmažodžiai sudaro priešpriešą nesangrąžiniams tranzityvumo pagrindu; kai kurie sangrąžiniai veiksmažodžiai vartojami kaip atitinkamu nesangrą̌̌inių veiksmažodžiu sinonimai. Kai kuriais atvejais sangrąža laikoma veiksmažodžiu darybos priemone, bet turi keletą apribojimu, pvz., sangrąža darybos priemone laikoma tik tada, kai sangražinis veiksmažodis ir pamatinis jo žodis sudaro darybos priešpriešą, t. y. skiriasi ne tik forma, bet ir reikšme, pvz., dairytis, didžiuotis (žr. Dabartinés lietuviu kalbos gramatikq 1996, p. 406-405). Taigi dèl sangrąžos kategorijos sudetingumo pasirinktas paprasčiausias analizès būdas: varijuojančios sangrąžinès ir nesangrąžinès formos laikomos morfologijos variantais, nes tai nera reguliari visiems veiksmažodžiams būdinga kaityba, taip pat tai nèra iprastinè veiksmažodžiu darybos priemonè. 
2 lentelè. Morfologinis variantiškumas

\begin{tabular}{l} 
Morfologinio variantiškumo tipas \\
1.1. Giminès variantiškumas \\
\hline 1.2. Skaičiaus variantiškumas
\end{tabular}

1.3. Ivardžiuotinès ir neivardžiuotinès formų variantiškumas

Morfologinio variantiškumo pavyzdžiai

\section{Daiktavardiniai pastovieji junginiai}

Komisijos narys - komisijos narè; laidos vedèjas - laidos vedèja; atstovas spaudai - atstovè spaudai; darželio auklètojas - darželio auklètoja; generalinis direktorius - generalinè direktorè; operos solistas - operos solistė; politinis kalinys - politinè kalinè

Iš pradžios - iš pradžių (F); autoriaus teisè - autorių teisès; oro prognozè - orų prognozè; pardavimo vadovas - pardavimų vadovas

Paskutinè valanda - paskutinioji valanda (F); nauji metai - naujieji metai, ketvirti metai - ketvirtieji metai; šventas raštas - Šventasis Raštas; Šventas Tèvas - Šventasis Tèvas; sèdimas darbas sèdimasis darbas; gyvenama vieta - gyvenamoji vieta; laimejusi partija - laimèjusioji partija; artimas užsienis - artimasis užsienis; oficiali dalis - oficialioji dalis; naujas karas - naujasis karas

1.4. Sangrąžinès ir nesangrąžinès formos variantiškumas

Valiutos keitimas - valiutos pasikeitimas; euro j̇edimas - euro j̨sivedimas

Laipteliu aukštyn - laipteliu aukščiau (F); ilgi metai - ilgesni metai, ilgiausi metai; geri metai - geresni metai, geriausi metai; gražūs metai - gražiausi metai; didžioji partija - didžiausia partija; maža partija - mažesnioji partija; svarbios varžybos - svarbiausios varžybos; ekonomiškas sprendimas - ekonomiškiausias sprendimas; lengvas sprendimas - lengviausias sprendimas; nauji duomenys naujausi duomenys; tikslūs duomenys - tikslesni duomenys; linksmoji dalis - linksmiausia dalis

1.6. Ilgosios ir sutrumpèjusios formos variantiškumas

Išlikti atmintyje - išlikti atminty; metų pradžioje - metų pradžioj; lygioje vietoje - lygioj vietoj; kvailio vietoje - kvailio vietoj

\subsection{Skaitvardžių tipų variantiškumas}

Du metai - dveji metai, dvejetas metu; trys metai - treji metai; septynios rungtynès - septynerios rungtynès; penkios rungtynès - penkerios rungtynès

1.8. Kaitomosios ir nekaitomosios skaitvardžio formos variantiškumas

Trisdešimt metu - trisdešimtis metų

\section{Veiksmažodiniai pastovieji junginiai}

2.1. Sangrąžinès ir nesangrąžinès formos variantiškumas

Atverti kelią - atsiverti kelias (F); sulaukti dèmesio - susilaukti dèmesio; jvesti eurą - isivesti eurą; pastatyti automobili - pasistatyti automobili; užsakyti automobili - užsisakyti automobili; kelnes numauti - kelnes nusimauti $(F)$

Bègti metai - bėgantys metai; prabėgti metai - prabėgę metai, prabėgantys metai; baigti darbą - baigiamasis darbas; nuveikti darbą - nuveiktas darbas, nuveikiamas darbas; gyventi užsienyje - gyvenantis užsienyje; balsuoti užsienyje - balsuojantis užsienyje; išrinkti pirmininką išrinktas pirmininkas; rengti varžybas - rengiamos varžybos; skųsti sprendimą - skundžiamas sprendimas; priimti sprendimą - priimtinas sprendimas; neatidèlioti sprendimo - neatidèliotinas sprendimas

Praejęs sezonas - praeitas sezonas; vykdantysis direktorius - vykdomasis direktorius; vadovaujamas darbas - vadovaujantis darbas; numatytas darbas - numatomas darbas; pasiaukojamas darbas - pasiaukojantis darbas; pažeista vieta - pažeidžiama vieta

\section{Būdvardiniai pastovieji junginiai}

3.1. Ivardžiuotiniu ir nejvardžiuotiniu formų variantiškumas

Iš paskutinių - iš paskutiniuju (F)

3.2. Skaičiaus variantiškumas

Iki paskutiniosios - iki paskutiniuju (F)

\section{Prieveiksminiai junginiai}

4.1. Laipsnio variantiškumas

10 Sintaksiškai pagal pagrindini demeni (veiksmažodi arba daiktavardi) šis variantiškumas turètu būti klasifikuojamas kitaip (pvz., bẻgti metai - subjektinis, bégantys metai - atributinis junginys), bet kadangi varijuoja asmenuojamosios ir neasmenuojamosios veiksmažodžio formos, aptariama prie veiksmažodinių PJ ${ }^{\prime \prime}$ Sintaksiškai pagal pagrindini demeni (daiktavardi) šis variantiškumas turètų būti priskiriamas prie daiktavardiniu junginių, bet kadangi varijuoja dalyviu formos, todèl aptariama prie veiksmažodinių PJ. 


\section{Sintaksinis variantiškumas}

Sintaksinis variantiškumas šiame tyrime apima linksniu, prielinksnių, linksnių bei prielinksnių ir sintaksinių konstrukciju variantiškumą (žr. 3 lentelę). Nors leksinè PJ struktūra vienoda, tačiau gali kisti arba papildomai issiterpti prielinksnių, jungiamujju dalelyčių ir pan. Dažniausiai varijuoja linksniai ir prielinksniai.

\begin{tabular}{|c|c|}
\hline Sintaksinio variantiškumo tipas & Sintaksinio variantiškumo pavyzdžiai \\
\hline \multicolumn{2}{|r|}{ 1. Pastoviuju junginių variantiškumas } \\
\hline 1.1. Linksnių variantiškumas & $\begin{array}{l}\text { Gauti naudą - gauti naudos; numatyti laiką - numatyti laiko; sugaišti } \\
\text { laiką - sugaišti laiko; prarasti laiką - prarasti laiko; paskirti laiką - } \\
\text { paskirti laiko; atstovauti valstybę - atstovauti valstybei; pasiskirstyti } \\
\text { darbus - pasiskirstyti darbais }\end{array}$ \\
\hline $\begin{array}{l}\text { 1.2. Linksniu su prielinksniais } \\
\text { variantiškumas }\end{array}$ & Iki valios - iki valiai (F) \\
\hline \multicolumn{2}{|r|}{ 2. Sintaksinių konstrukcijų variantiškumas } \\
\hline $\begin{array}{l}\text { 2.1. Linksninių ir prielinksninių } \\
\text { konstrukciju variantiškumas }\end{array}$ & $\begin{array}{l}\text { Išskėstomis rankomis - su išskėstomis rankomis }(F) \text {; mielu noru - su } \\
\text { mielu noru }\end{array}$ \\
\hline $\begin{array}{l}\text { 2.2. Prielinksninių konstrukciju } \\
\text { variantiškumas }\end{array}$ & Iš paskutiniuju - iki paskutiniuju (F); iš naujo - per naujo \\
\hline 2.3. Kita & Liežuvis nesiverčia - kaip liežuvis apsiverčia (F) \\
\hline
\end{tabular}

Linksniu variantai vyrauja reiškiant objektą, kuri galima perteikti skirtingais linksniais: gauti naudq - gauti naudos; numatyti laikq - numatyti laiko; sugaišti laikq - sugaišti laiko; prarasti laikq - prarasti laiko; paskirti laikq; paskirti laiko. Viename frazeologizme užfiksuota sustabarejusi naudininko forma varijuoja su iprasta dabartinei kalbai forma - kilmininku: iki valiai - iki valios (F). Aplinkybinis būdo ryšys perteiktas su prielinksniu arba be jo: mielu noru - su mielu noru.

Taip pat varijuoja prielinksniai (iš paskutiniuju - iki paskutiniuju (F)) ir sintaksinès konstrukcijos (liežuvis nesiverčia - kaip liežuvis apsiverčia $(\mathrm{F})$ ).

Prie sintaksinio variantiškumo priskirtina PJ žodžių tvarkos kaita ir žodžiu isiterpimas. Analizuojami junginiai yra automatiškai nustatyti kaip pastovieji, kai kurie iš ju laikomi frazeologizmais, bet iš analizuojamos medžiagos akivaizdu, kad ir tokie junginiai gali varijuoti. Vadinasi, PJ būdinga lanksti leksinè ir gramatinè struktūra (Bielinskienè et al., 2017).

Žodžiu tvarkos kaita. Peržvelgus žodžių tvarkos kaitos pavyzdžius, akivaizdu, kad veiksmažodiniai junginiai leidžia daugiau žodžių tvarkos varijavimo (žr. 4 lentelę).

\begin{tabular}{|c|c|}
\hline Pastoviuju junginių tipas & Žodžiu tvarkos kaitos pavyzdžiai \\
\hline $\begin{array}{l}\text { 1. Daiktavardiniai } \\
\text { pastovieji junginiai }\end{array}$ & Atsparus vanduo - vanduo atsparus; stiprus vèjas - vèjas stiprus \\
\hline $\begin{array}{l}\text { 2. Veiksmažodiniai } \\
\text { pastovieji junginiai }\end{array}$ & $\begin{array}{l}\text { Iškarpyti plaukus - plaukus iškarpyti; iškilti problema - problema iškilti; } \\
\text { iškovoti pergalę - pergalę iškovoti; padidinti išlaidas - išlaidas padidinti; } \\
\text { palaikyti kompaniją - kompaniją palaikyti; kurti iliuziją - iliuziją kurti; } \\
\text { skirti dėmesi - demesi skirti; susilaukti vaiko - vaiko susilaukti; apsukti } \\
\text { galvą - galvą apsukti (F); sukti galvą - galvą sukti (F); nagrinèti bylą - bylą } \\
\text { nagrineti }\end{array}$ \\
\hline
\end{tabular}

4 lentelè Žodžių tvarkos kaita
3 lentelè

Sintaksinis variantiškumas 
5 lentelè

Isiterpimai i pastoviuosius junginius
Taip pat atkreiptinas demesys, kad ne visais atvejais, kai automatiškai nustatomas tų pačių žodžiu galimas vartojimas drauge, tik kita tvarka, tie žodžiai sudaro to paties PJ variantus. Pavyzdžiui, junginiai prekyba narkotikais ir narkotiku prekyba gali būti laikomi vienas kito gramatiniais variantais. Tačiau turto verte ir [kokios nors] vertés turtas jau yra du atskiri junginiai, turintys skirtingas reikšmes, todèl nelaikomi GV. Dalis automatiškai atpažjstamu galimu žodžiu tvarkos kaitos atvejų išvis nesudaro kolokaciju, pavyzdžiui, prevencijos skyrius - kolokacija, o skyriaus prevencijos, nors ir yra gana dažnas junginys (41 pavartojimas tirtame tekstyne), jo dèmenys nèra susiję sintaksiniais ryšiais ir todèl pagal taikomas apibrěžtis išvis nelaikomas kolokacija.

Šio tyrimo duomenimis galima netiesiogiai patvirtinti anglu kalbos tyrimų išvadas, kad vienas kuris nors žodžių tvarkos variantas dažniausiai dominuoja, nors kiti variantai irgi yra imanomi. Toks dominavimas atrodo itin aktualus daiktavardiniams junginiams, nes daiktavardiniu PJ žodžiu tvarkos varijavimo užfiksuota gerokai mažiau nei veiksmažodinių. Taip pat duomenu analize išryškino tai, su kokiais automatinio kolokaciju atpažinimo iššūkiais galima susidurti. Nors žodžiu tvarkos sukeitimas atpažistant junginius atrodo lengvai automatiškai igyvendinama užduotis, ne visi taip atpažinti tų pačiu žodžiu pavartojimo drauge atvejai yra sintaksiškai susijusios kolokacijos.

lsiterpimai i PJ. Pažvelgus i veiksmažodiniu junginių pavyzdžius, matyti, kad isiterpiančių žodžių sintaksinis ryšys su PJ gali būti skirtingas (žr. 5 lentelę).

\begin{tabular}{|c|c|}
\hline Pastoviuju junginių tipas & lsiterpimų pavyzdžiai \\
\hline \multicolumn{2}{|r|}{ 1. Daiktavardiniai pastovieji junginiai } \\
\hline 1.1. Vieno žodžio įsiterpimai & Aistringas [beisbolo] gerbèjas; magiškomis [vietovès] galiomis \\
\hline 1.2. Ilgesni įsiterpimai & $\begin{array}{l}\text { Turistinei [dešimties dienų] kelionei; grynas [Austrijos, Vokietijos ar } \\
\text { Prancūzijos Alpių kalnų] oras; atspirties [prieš Rusiją] tašką; sklandų } \\
\text { [euro ivedimo] procesą }\end{array}$ \\
\hline \multicolumn{2}{|r|}{ 2. Veiksmažodiniai pastovieji junginiai } \\
\hline 2.1. Vieno žodžio ỉsiterpimai & $\begin{array}{l}\text { Laiką [ramiai] leidžia; atveria [daugybę] galimybių; naudos } \\
\text { [studentams] nesuteikia; tikslas, [kurio] siekti }\end{array}$ \\
\hline 2.2. Ilgesni ¿̨siterpimai & $\begin{array}{l}\text { Pelnė [metų gražiausios grupės moters] titulą; nesėkmes } \\
\text { [pirmają dieną] patyre; kelia [atsakomybės už karo nusikaltimus } \\
\text { ir nusikaltimus žmoniškumui, neteisètos prekybos ginklais, } \\
\text { tarptautinès humanitarinès teisės pažeidimu, seksualinio smurto, } \\
\text { moterų ir vaikų apsaugos konfliktuose] klausimus }\end{array}$ \\
\hline
\end{tabular}

Galimi isiterpimai, kurie modifikuoja daiktavardi (pelné [gražiausios grupés moters] titulq) arba veiksmažodi (laikq [ramiai] leidžia); isiterpti gali veiksmažodžio objektas (naudos [studentams] nesuteikia) arba isiterpiantis dèmuo gali prijungti šalutini sakini (tikslas, [kurio] siekti...) - tokiu atveju sakiniu ribos kolokacijai negalioja.

Analizuojant daiktavardinius PJ, atrodo, kad daugiausia pasitaiko papildomai daiktavardi pažyminčiu žodžiu - dominuoja nederinamieji pažyminiai (aistringas [beisbolo] gerbejas). Pastebètina, kad modifikuojamas gali būti tiek daiktavardis, tiek ji pažymintis žodis (atspirties [prieš Rusijq] taškq).

\section{Kelių tipų variantiškumas}

Analizuojant tiriamają medžiagą, išryškejo keliu tipu variantiškumas, apimantis tiek darybini, tiek morfologini, tiek sintaksini variantiškumą. 
Remiantis analizuotais junginiais, galima skirti to paties tipo variantiškumą, kai variantų atsiranda to paties tipo viduje, pvz.:

a) darybinis variantiškumas: (1) nepriešdèlinės - priešdèlinės formos ir veiksmažodžio - veiksmažodinio daiktavardžio formos variantiškumas: galvq sukti - galvq pasukti - galvos sukimas (F); (2) vienas priešdèlis - du priešdèliai: liežuvis nesiverčia - liežuvis neapsiverčia $(\mathrm{F})$.

b) morfologinis variantiškumas: jvardžiuotinè forma ir skaičius: trečiosios valstybès - trečia valstybe (išsamiau žr. 1-2 lenteles).

Taip pat skirtinas kelių tipų variantiškumas, kai varijuojama tarp dvieju skirtingų variantiškumo tipu, pvz.:

a) darybinis ir sintaksinis: kelti klausimq - iškelti klausimq - klausimq iškelti; slopinti jèga nuslopinti jega - jéga slopinti;

b) darybinis ir morfologinis: naujuosius sutikti - naujuosius pasitikti.

Kalbant apie gramatinio variantiškumo kaip reiškinio atsiradimo priežastis, darytina išvada, kad variantų atsiranda dèl formu sinonimijos ir jvairių raiškos galimybių, taip pat dèl taisyklingumo aspekto ir skirtingos vartosenos sferos. Tekstyne šalia taisyklingos formos gali egzistuoti netaisyklinga forma ir taip sudaryti gramatini variantiškumą, pvz., du metai - dveji metai. Šalia oficialiosios vartosenos atsiranda laisviesiems stiliams būdinga vartosena: išlikti atmintyje - išlikti atminty, išskéstomis rankomis - išskéstom rankom ar konstrukcijoje sustabarèjęs, tarmèse išlikęs variantas: iki valiai - iki valios ir pan.

Analizuojant gramatini variantiškumą, pastebèta, kad kartais viena iš varijuojančių formų labai dominuoja, o kitas gramatinis variantas labai retas ir laikomas tik teoriškai galimu, pvz., vienaskaita labai reta, o dažniausiai vartojama daugiskaita: asmens duomenys, duomenu baze, kvépavimo takai, išleisti pinigus; aukščiausiasis laipsnis: artimiausiomis dienomis. Tas pats pasakytina ir apie kurio nors linksnio dominavimą. Iš formų dažnumo duomenu matyti, kad kai kurie PJ dažniausiai vartojami tik vienu kuriuo linksniu, pvz., pastaraisiais metais, progai pasitaikius, lengva širdimi ir pan. (plačiau žr. Rimkute et al., 2015). Kai kurie frazeologizmai gali turèti tik neigiamają formą: galvoje netilpti.

Akcentuojant praktini šio tyrimo aspektą, galima paminèti, kad, tiriant PJ vartoseną tekstyne, gaunama dažniausiai daug kaitybinių formu, kurios rodo, kokia forma PJ paplitęs vartosenoje, bet tarp ju neretai galima rasti ir GV. Ir kaitybinès formos, ir GV yra svarbūs PJ lemai nustatyti - tai ypač svarbu automatinei analizei, nes automatiškai kaip lema nustatomas junginys aukšta mokykla, nors lema turètų būti aukštoji mokykla arba aukštesnioji mokykla (plačiau apie automatini PJ lemos nustatymą žr. Boizou et al., 2015).

Šiame straipsnyje aprašytas kol kas lietuvių lingvistų menkai analizuotas PJ (ypač kolokaciju) gramatinis variantiškumas. Juo laikomi skirtingi to paties PJ pavidalai, besiskiriantys žodžiu darybos, morfologijos ir (ar) sintaksès elementais.

Gramatinis variantiškumas skirstytas i tris tipus: darybini, morfologini ir sintaksini. Nors atlikta tik kokybinè variantiškumo analizè, iš turimu duomenu matyti, kad daugiausia yra morfologinio variantiškumo tipu.

Darybinis variantiškumas apima priešdèlių, priesagų, veiksmažodžio ir veiksmažodinio daiktavardžio formų variantus ir būdingas daiktavardiniams bei veiksmažodiniams PJ.

Morfologinis variantiškumas būdingas daiktavardiniams, veiksmažodiniams, būdvardiniams ir prieveiksminiams PJ. Morfologiniais variantais laikomi tokie atvejai, kai to paties PJ formos skiriasi gramatinemis kategorijomis ir tai nelaikoma reguliaria kaityba, nes dažniausiai išryškèja viena ar kelios dominuojančios kaitybinès formos. Tarp morfologinių variantų daž-

Apibendrinamosios pastabos 
nai išryškejja terminu ir terminais nelaikytinu kolokaciju variantiškumas, nes jvardžiuotinès, aukštesniojo ar aukščiausiojo laipsnio, daugiskaitos formos (jos neretai dominuoja tarp tam tikro PJ kaitybiniu formų) laikytinos terminais. Tarp morfologiniu variantu gausa išsiskiria varijuojančios to paties $\mathrm{PJ}$ formos, iš kuriu vienose pavartotos asmenuojamosios veiksmažodžio formos, o kitose - neasmenuojamosios (dažniausiai dalyviai).

Sintaksinis variantiškumas apima linksnių, prielinksnių, linksnių ir prielinksnių, sintaksinių konstrukcijų variantiškumą. Taip pat galima žodžių tvarkos kaita ir kitu žodžių isiterpimas i PJ. Dažniausiai varijuoja linksniai ir prielinksniai. Žodžių tvarkos kaita būdingesnè veiksmažodiniams PJ. Isiterpimai i PJ gali būti tiek vienažodžiai, tiek keliažodžiai; jie būdingi tiek veiksmažodiniams, tiek daiktavardiniams junginiams.

Gramatinis variantiškumas gali būti vieno tipo, pvz., sintaksinis, bet gali būti ir keliu tipu (pvz., žodžiu darybos ir morfologijos). Gramatinis variantiškumas būdingesnis veiksmažodiniams ir daiktavardiniams PJ nei iš kitų kalbos dalių sudarytiems junginiams.

Pastebèta ypatybė, kad kolokaciju gramatinio variantiškumo raiška yra įvairesnè nei frazeologizmų, todèl gramatinis variantiškumas būdingesnis kolokacijoms, bet iš dalies tai gali būti nulemta ir tiriamosios medžiagos, nes joje daugiausia rasta kolokaciju.

Kadangi šis tyrimas yra žvalgomasis, klasifikacija nèra galutinè, gali kelti diskusijų, tačiau tikimasi, kad straipsnyje aprašyti duomenys bus vertingi tolesniems PJ gramatinio variantiškumo tyrimams.

\section{Literatūra}

1 Abeillé, A., 1995. The flexibility of French Idioms: A representation with lexicalized tree adjoining grammar. Idioms: Structural and psychological perspectives (eds.) M. Everaert, E. van der Linden, A. Schenk, R. Schreuder, Hillsdale, NJ: Lawrence Erlbaum Associates, pp. 15-42.

2 Ambrazas, V., 2012. Žodžių tvarka ir baltų kalbu sakinio tipo rekonstrukcija. Baltistica, no. 18(2), pp.100-118. https://doi.org/10.15388/ baltistica.18.2.1551 [žiūrèta kovo 30, 2018].

3 Bielinskienè, A., Kovalevskaitè, J., Rimkutè, E., Vilkaitè, L., 2017. Kolokaciju ir frazeologizmų atpažinimo kriterijai. Kalbų studijos, no. 31, pp. 83-101. http://kalbos.ktu.lt/index.php/ KStud/article/view/18710 [žiūrèta kovo 15, 2018].

4 Boizou, L., Kovalevskaitè, J., Rimkutè, E., 2015. Automatic Lemmatisation of Lithuanian MWEs. Proceedings of 20th Nordic Conference of Computational Linguistics NODALIDA 2015 (ed.) B. Megyesi, NEALT proceedings, vol. 23. Linköping: ACL anthology, pp. 41-49. https://aclanthology.coli. uni-saarland.de/papers/W15-1808/w151808 [žiūrèta balandžio 10, 2018].
5 Bumbulienè, I., Mandravickaitè, J., Boizou, L. Krilavičius, T. 2017. An overview of Lithuanian Internet media n-gram corpus. SYSTEM 2017: Symposium for Young Scientists in Technology, Engineering and Mathematics. CEUR Workshop Proceedings, pp. 24-28. http://ceur-ws.org/Vol-1853/ [žiūrèta gruodžio 8, 2018].

6 Bumbulienè, I., Mandravickaitė, J., Bielinskienè, A., Boizou, L., Kovalevskaitè, J., Rimkutè, E., Vilkaite-Lozdienè, L., Man, K. L., Krilavičius, T., 2018. RNNs for Lithuanian Multiword Expressions Identification. International Journal of Design, Analysis and Tools for Integrated Circuits and Systems (IJDATICS), 7 (1). Hong Kong: Solari Co, pp.44-47. http://mwe. lt/wp-content/uploads/2018/12/CICET2018_ Proceedings.pdf [žiūrèta gruodžio 8, 2018].

7 Burger, H., 1998. Phraseologie. Eine Einführung am Beispiel des Deutschen. Berlin: Erich Schmidt.

8 Čermák, F., 2007. Foundations and Principles of Phraseology and Idiomatics. In: Czech and General Phraseology. Praha: Carolinum.

9 Dabartinès lietuvių kalbos gramatika, red. V. Ambrazas, 1996. Vilnius: Mokslo ir enciklopedijų leidykla. 
10 Evert, S., 2009. Corpora and collocations. In: Corpus Linguistics: An International Handbook 2, (eds.) Lüdeling A. and Kytö M., Berlin, Boston: De Gruyter Mouton, pp. 1212-1248. https://doi.org/10.1515/97831 10213881.2.12 12 [žiūrèta balandžio 15, 2018].

11 Fedulenkova, T., 2005. Frazeologičeskaja variantnostj kak lingvističeskaja problema. Vestnik OGU 4, pp.62-69.

12 Fellbaum, Ch., Geyken, A., Herold, A., Koerner, F., Neumann, G., 2006. Corpus-based Studies of German Idioms and Light Verbs. International Journal of Lexicography, no. 19(4), pp. 349-360. https://doi.org/10.1093/ijl/ecl031

13 Firth, J. R., 1957. A synopsis of linguistic theory 1930-1955. In: Selected papers of Firth 1952-1959, (ed.) Palmer F., London: Longman, pp. 168-205.

14 Heid, U. 2008. Computational Phraseology. In: Phraseology - an Interdisciplinary Perspective. Amsterdam/Philadelphia: John Benjamins Publishing, pp. 337-360. https://doi. org/10.1075/z.139.28hei

15 Hemmerling, E., 1989. Dèl lietuvių kalbos nominatyvinių frazeologizmų leksinių variantų. Baltistica, suppl. 3(2), pp. 297-300.

16 Judžentis, A., 2012. Lietuvių kalbos gramatinès kategorijos. Vilnius: Vilniaus universiteto leidykla.

17 Klimas, A., 2002. Lithuanian in the $21^{\text {st }}$ Century: Linguistic Snippets and Tidbits. In Lithuanian Quarterly Journal of Arts and Sciences, no. 48(3). http://www.lituanus. org/2002/02_3_06.htm [žiūrèta liepos 1, 2018].

18 Krishnamurthy, R., Sinclair, J., Daley, R., Jones, S., 2004. English collocation studies: the OSTI report. London: Continuum.

19 Mandravickaitè, J., Rimkutè, E., Krilavičius, T. 2016. Hybrid Approach for Automatic Identification of Multi-Word Expressions in Lithuanian. Proceedings of the Seventh International Conference Baltic HLT 2016. Amsterdam, Berlin, Tokyo, Washington, DC: IOS Press, pp. 153-159.

20 Marcinkevičienè, R., 2010. Lietuvių kalbos kolokacijos. Kaunas: Vytauto Didžiojo universiteto leidykla. http://vddb.laba.lt/
fedora/get/LT-eLABa-0001:B.03 2010 ISBN_978-9955-12-656-0/DS.001.0.01.B00K [žiūrèta liepos 12, 2018].

21 Moon, R., 1998. Fixed Expressions and Idioms in English. A corpus-based approach. Oxford: Clarendon Press.

22 Paulauskienè, A., 1957. Varianty frazeologičeskich edinic $v$ sovremennym anglijskom jazyke. Maskva.

23 Pikčilingis, J., 1969. Leksinè ir gramatinè sinonimika. Kaunas: Šviesa.

24 Pikčilingis, J., 1975. Lietuvių kalbos stilistika. Vilnius: Mokslas.

25 Rimkutè, E., Bielinskienè, A., Kovalevskaite, J. (sud.), 2012. Lietuvių kalbos daiktavardinių frazių žodynas. Kaunas: Vytauto Didžiojo universitetas. http://donelaitis.vdu.lt/lkk/pdf/ daikt_fr.pdf [žiūrèta birželio 20, 2018].

26 Rimkute, E., Kovalevskaitè, J., 2015. Lietuviu kalbos daiktavardiniu frazių žodyno vienaformiai pastovieji junginiai. Darbai ir dienos, no. 64, pp. 153-167.

27 Sag, I. A., Baldwin, T., Bond, F., Copestake, A., Flickinger, D., 2002. Multiword expressions: A pain in the neck for NLP. In: Computational Linguistics and Intelligent Text Processing, (ed.) A. Gelbukh A., Berlin: Springer., pp. 1-15. https://doi.org/10.1007/3-540-45715-1_1

28 Sinclair, J., 1991. Corpus, concordance, collocation. Oxford: Oxford University Press.

29 Valiulytè, E., 1998. Dabartinès lietuvių kalbos sintaksiniai sinonimai. Vilnius: Mokslo ir enciklopedijų leidybos institutas.

30 Wray, A., 2002. Formulaic Language and the Lexicon. New York: Cambridge University Press. https://doi.org/10.1017/ CB09780511519772

31 Župerka, K., 2001. Stilistika. Šiauliai: Šiaulių universitetas.

Šaltiniai

1 DELFI.lt tekstynas. 
The paper analyses grammatical variation of two types of formulaic sequences: collocations and idioms. The formulaic sequences were automatically extracted from the DELFI.lt corpus. It was noticed that formulaic sequences are used in different forms that cannot be seen as simple inflections. Their grammatical variation was classified into the following categories:

1 Derivational variation: when one sequence has an affix and another one, which can be seen as its variant, has not. E.g., nutekejo protai - protu nutekejimas; ekonomikos krize ekonomine krize;

2 Morphological variation: when number, gender or other grammatical categories vary. E.g., euro ivedimas - euro isivedimas; iš pradžios - iš pradžiu; vykdomasis direktorius - vykdantysis direktorius;

3 Syntactic variation: when the noun cases or prepositions vary, e.g., išskèstomis rankomis su išskéstomis rankomis, other words are inserted, e.g., aistringas [beisbolo] gerbejjas, or word order changes, e.g., skirti demesi - demesi skirti.

Grammatical variation seems to be more typical for collocations than for idioms. Also, in about 14 thousand formulaic sequences analysed, collocations were far more frequent than idioms, so the paper mostly gives examples of grammatical variation of collocations. The paper presents a qualitative report because there have been almost no works on grammatical variation of Lithuanian formulaic sequences so far and for this reason it is important to describe and classify the phenomenon.

\section{Apie autores \\ Agnè \\ Bielinskienè \\ Dr., Vytauto Didžiojo \\ universitetas \\ Mokslinių tyrimų \\ sritys \\ Tekstynų lingvistika, pastovieji junginiai, automatiné kalbos analizè}

Adresas
V. Putvinskio g. 23-216
LT-44243 Kaunas,
Lietuva
El. paštas
agne.bielinskiene@
vdu.lt

\section{Jolanta Kovalevskaitė \\ Dr., Vytauto Didžiojo universitetas \\ Mokslinių tyrimų sritys Tekstynu lingvistika, pastovieji junginiai, terminologija ir leksikografija}

Adresas

V. Putvinskio g. 23-216

LT-44243 Kaunas, Lietuva

\section{El. paštas} jolanta.kovalevskaite@ vdu.lt

\section{Erika \\ Rimkutė}

Doc. dr., Vytauto Didžiojo universitetas

\section{Mokslinių tyrimu} sritys Tekstynų lingvistika, kompiuterine lingvistika, automatine gramatinè analizè pastovieji junginiai

\section{Adresas}

V. Putvinskio g. 23-216

LT-44243 Kaunas,

Lietuva

El. paštas erika.rimkute@vdu.lt

\section{Laura Vilkaité- Lozdiené}

Dr., Vilniaus universitetas

Mokslinių tyrimų sritys

Antrosios kalbos leksikos isisavinimas, pastovieji junginiai, psicholingvistika

\section{Adresas}

Universiteto g. 5

LT-01513 Vilnius, Lietuva

\section{El. paštas} laura.vilkaite@fff.vu.lt 